\title{
THE ANALYSIS OF RURAL-URBAN LINKAGE IN ACEH SINGKIL DISTRICT
}

\author{
Hilda Syahrani ${ }^{1}$, Agus Purwoko ${ }^{2}$, Rujiman ${ }^{3}$ \\ ${ }^{1}$ Mahasiswa Magister Perencanaan Wilayah dan Pedesaan, Universitas Sumatera Utara \\ 2,3Magister Perencanaan Wilayah dan Pedesaan, Universitas Sumatera Utara \\ Jl. Dr. T. Mansur No. 9 Padang Bulan, Medan, Sumatera Utara, 20155, Indonesia \\ E-mail: hildasyahranipasaribu@gmail.com
}

Received: 22 May 2020, Repaired: 11 December 2020, Approved: 09 January 2021

\begin{abstract}
Aceh Singkil District is an agricultural area whose the economic activities are dominatated by the farm. There are indications that the economic linkages between rural and urban area have not fully supported the oil-palm farm activities. It resulted the regional development process did not run optimally, so that, it has not made a significant contribution to the public's welfare. This study aims to identify the economical linkage between the rural and urban areas in Aceh Singkil District. This study used a qualitative approach with the data collection methods through interviews that were descriptively analyzed. The economical linkage can be seen from the capital flow, the shopping flow, the raw material flow, the intermediate goods flow, and the income flow. Based on the linkages between urban and rural areas, it is related to the condition of regional development in Aceh Singkil District. The results showed that the economical linkage were well-established is the shopping flow, while the capital flow was less bind up with villages in the urban area. There were also the raw material flow, the intermediate goods flow, and the income flow that were not absolutely interrelated. The intermediate good flow was binding up with the outside region, so that the acquisition of added value entered other areas. The implication from the conditional linkage of rural and urban areas in the regional development context is that the rural and urban areas are less functionally intertwined. It resulted the high poverty rates in Aceh Singkil District.
\end{abstract}

Keywords: Regional Development, Economical Linkage, Rural-Urban Areas, OilPalm

\begin{abstract}
Abstrak
Kabupaten Aceh Singkil merupakan daerah pertanian yang kegiatan ekonominya didominasi oleh pertanian. Terdapat indikasi bahwa keterkaitan ekonomi antara pedesaan dan perkotaan belum sepenuhnya mendukung kegiatan perkebunan kelapa sawit. Hal tersebut mengakibatkan proses pembangunan daerah tidak berjalan secara optimal sehingga belum memberikan kontribusi yang berarti bagi kesejahteraan masyarakat. Penelitian ini bertujuan untuk mengidentifikasi keterkaitan ekonomi antara pedesaan dan perkotaan di Kabupaten Aceh Singkil. Penelitian ini menggunakan pendekatan kualitatif dengan metode pengumpulan data melalui wawancara yang dianalisis secara deskriptif. Keterkaitan ekonomi dapat dilihat dari arus modal, arus belanja, arus bahan baku, arus barang antara, dan arus pendapatan. Berdasarkan keterkaitan antara perkotaan dan perdesaan, hal tersebut terkait dengan kondisi pembangunan daerah di Kabupaten Aceh Singkil. Hasil penelitian menunjukkan bahwa keterkaitan ekonomi yang mapan adalah arus belanja, sedangkan arus modal kurang terikat dengan desa-desa di kawasan perkotaan. Aliran bahan mentah, aliran barang antara, dan aliran pendapatan tidak saling terkait secara mutlak.
\end{abstract}


Aliran barang menengah itu mengikat dengan daerah luar, sehingga nilai tambah masuk ke daerah lain. Implikasi dari keterkaitan kondisional pedesaan dan perkotaan dalam konteks pembangunan wilayah adalah bahwa perdesaan dan perkotaan kurang terjalin secara fungsional. Hal tersebut mengakibatkan tingginya angka kemiskinan di Kabupaten Aceh Singkil.

\section{Kata Kunci: Pembangunan Wilayah, Keterkaitan Ekonomi, Perdesaan-Perkotaan, Kelapa Sawit}

\section{INTRODUCTION}

Each region has the availability of certain natural resources. Humans is using the natural resource to fulfill their needs in their areas, but if it is not available, they will fulfill them from other areas that provide them. This condition will create a pattern relationship of human's fulfilled needs between regions (Aulia, 2020). The regions relationship is a form of linkage between regions, and one of them is the rural-urban area.

According to Akkonyunlu (2016), the rural-urban linkages have a supplydemand characteristic, this can be seen from the relationship between villages as an agricultural producers who depend on the urban market, and vice versa, the urban market requires the distribution from the rural agricultural products. In addition, referring to the urban functions as the service centers, Rondinelli (1985) and Douglass (1998) state the urban area is expected to play a role in spreading progress for residents in the rural or hinterland area based on the spead effect and the existence of economy scales.

The key of regional development strategy is the formation of rural-urban linkage (2014). The non-optimal condition of the bound up rural-urban linkage can be a factor in causing poverty in the two regions. Basically, an area will need each other to fulfill the daily needs of the society in it, so that, if the rural or urban areas are constrained by the accessibility and have limited human resources and the natural resources will be caused of increasing poverty.

Aceh Singkil District actually has a potentially natural resources to be developed in the agricultural sector, especially through the oil- palm commodity. Several data that can represent this potential are: (1) the contribution of the agricultural sector ranks in the first towards the economy of Aceh Singkil, which is $28.57 \%$ (BPS Aceh Singkil District, 2019), (2) the results of agriculture in Aceh Singkil are mostly supplied by sub-sector farm, which is $12.51 \%$, (BPS Aceh Singkil District, 2019), (3) the percentage of oilpalm area is $87.79 \%$, while the other plantation crops are only $12.21 \%$ (The Forestry and Plantation Office of Aceh Singkil District, 2019), (4) Agriculture is a business field that absorbs the most labor, and mostly dominated by the plantation households $42.24 \%$ (The Forestry and Plantation Office of Aceh Singkil District, 2019), and (5) The plantation sector is supported by the existence of oil- palm company that has a processing palm oil factory or Crude Palm Oil (CPO), namely PT. Naffasindo, PT Runding Putra Persada, PT Astra Agro Lestari. PT Socfindo, and PT Delima Makmur (BPS Aceh Singkil District, 2019).

The existence of the processing oilpalm industry in Aceh Sengkil District should help the public's economical and regional growth, but the reality in the field has not given much differences yet. This is indicated by the high percentage of poor people until 2019, which is 21.25 percent (BPS Aceh Singkil District, 2019).

Poverty in the rural area is closely related to the rural-urban interaction, especially in economical linkage context. There are indications that the efforts to develop the area in Aceh Singkil District have not been optimal, especially to support the farm's commodity flow, and one of the things that shows the symptom 
is the absence of a processing oil-palm factory into a finished goods in Aceh Singkil District. According to Rondinelli (1985), the absence of accessibility towards the integrated market centers, so the rural residents will experience difficulties in marketing an agricultural product, difficult to obtain an inputoutput production, modernize an agricultural pattern, adjust the product among the market's taste or a consumer, and get a needed services to improve the quality of life in the rural area.

Based on a review of these problem, the focus of this study is the economical relationship between rural-urban area, especially on the oil- palm plantation context. The production flow of plantation and the interaction with urban service facilities are an indicator of the processing economically linkage between rural and urban in Aceh Singkil District.

\section{METHODS}

This study of rural-urban linkage used a qualitative approach to identify the economical linkage and the implication of regional development. The scope in this study is the district, with the used analysis unit is the village according to its regional function. The location research is in the Aceh Singkil District which administratively consists of 116 villages. The classification of Rural Villages and Urban Villages in Aceh Singkil District refer to BPS Regulation No. 37/2010 which consists of 103 Rural Villages and 13 Urban Villages. Rural and Urban Maps in Aceh Singkil District can be seen in Figure 1.

The research method that is used was a survey based on the primary data. The primary data in this study were taken using a purposive sampling which focused on informants who have a good experience and knowledge. According to Sugiyono (2016), a purposive sampling is a technique of sampling data sources with certain considerations.

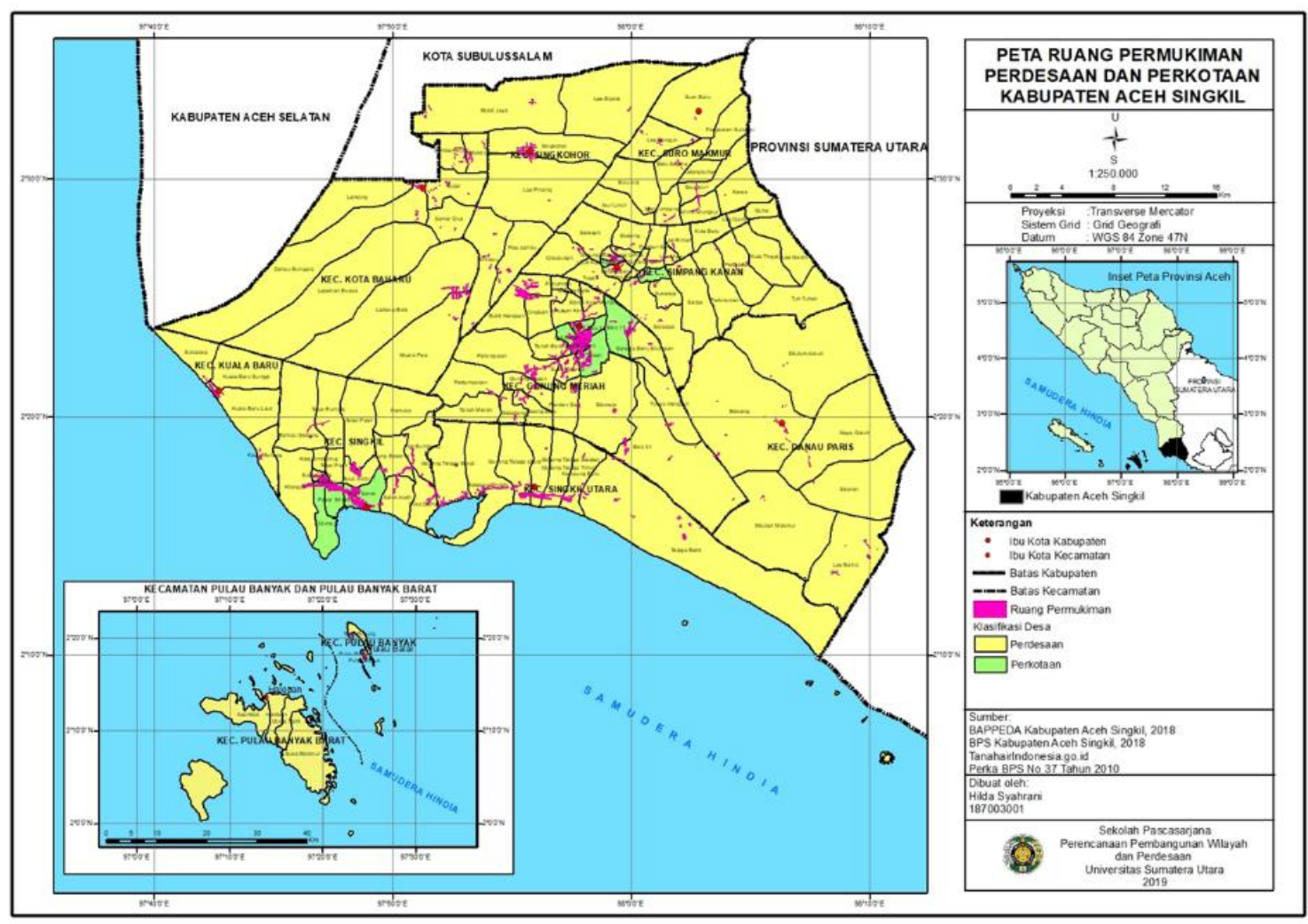

Figure 1. Maps of the Rural and Urban Residential Space in the Aceh Singkil District 
The referred informants are: (1) There are eight head of farmer groups, with the consideration that the head of farmer group is considered to have the capacity and understandability the situation in the field. The eight head of farmer groups who were appointed as informants were selected by considering the area of plantation land in each farmer groups which is spread across eight subdistricts. The elected head of farmer group are scattered in: Suka Damai Village, Ketapang Indah Village, Tanah Merah Village, Pangkalan Sulampi Village, Sukarejo Village, Lae Pinang Village, Sumber Mukti Village, and Biskang Village, and (2) The Factory's Head of Administration (KTU) as many as one person, with the consideration that the factory's head of administration has an understanding to the industrial substance of processing oil-palm and the head of administration intended as an informant who operating in the oil-palm factory which has the widest plantation namely PT Naffasindo, Bukit Harapan Village.

Primary data were collected by the survey methods through the interview with the aims to extract an information about the economically linkage of ruralurban area in the oil-palm plantation context. The data analysis technique of economical linkage are implemented by analyzing the element of economical linkage between farmer groups and industrial process, also the interaction with urban service facilities, namely: 1) the capital flow, (2) the shopping flow, (3) the raw material flow, (4) the intermediate good flow, and (5) the income flow (Rondinelli, 1985).

Table 1. Elements Category, and Study Focuses of Economical Linkage

\begin{tabular}{|c|c|}
\hline Elements & Focus of the Study \\
\hline The Capital Flow & $\begin{array}{l}\text { The Capital flow is seen from the use of capital by oil-palm farmer, and the received } \\
\text { capital resources is used by the oil-palm farmer in managing the farming business } \\
\text { and its marketing. }\end{array}$ \\
\hline The Shopping Flow & The farming tool is used by farmers in the plantation business. \\
\hline $\begin{array}{l}\text { The Raw Material } \\
\text { Flow }\end{array}$ & $\begin{array}{l}\text { The oil-palm commodity flow in the form of oil-palm bunches between villages in } \\
\text { Aceh Singkil District. }\end{array}$ \\
\hline The Intermediate & The oil-palm commodity flow in the form of Crude Palm Oil (CPO) between villages \\
\hline Goods Flow & in Aceh Singkil District and who come out from Aceh Singkil District. \\
\hline The Income Flow & $\begin{array}{l}\text { The income flow from the buying-selling process comodities and its industrial } \\
\text { process. }\end{array}$ \\
\hline
\end{tabular}

Source : Rondinelli, 1985 (modified)

As for the data of economical linkage from the primary data which are interpreted based on the ordinal data, is the data that got from the categorization and classification. The classification of economical linkage refers to the interview results related to local preference (rural or urban area) which accessed by eight farmer groups to fulfill the capital, the farming tool, the distribution of oil-palm fruit bunches, and the local preference of CPO distribution from the oil-palm's company. The higher prefention of location for fulfillment needs to the urban area, the better the linkages, and vice versa. The detailed classification are:

Table 2. The Element Classification of Economical Linkages in the Rural and Urban Area

\begin{tabular}{lll}
\hline No. & \multicolumn{1}{c}{ Percentage $(\%)$} & Category \\
\hline 1 & $1-33.33$ & Low \\
2 & $33.34-66.66$ & Medium \\
3 & $66.67-100$ & Good \\
\hline
\end{tabular}

Source : Arikunto, 2010 (modified) 


\section{RESULTS AND DISCUSSION}

The condition in the field showed that the certain obstacle of economical linkages between the rural and urban area in Aceh Singkil district. The analysis sequence of several indicators in economical linkages between the rural and urban area are the flows in: (1) capital, (2) shopping, (3) raw material, (4) intermediate goods, and (5) income, can be described as follows:

\section{The Capital Flow}

The sustainability of the farm as the form of production that is determined by the capital quantity's farmer. The capital in farming is the merge of land clearing costs and farming tool costs. At the end, the total of capital's farmer influenced towards the sustainability of the oil-palm plantation business and the received income. Related to this thing, one of the urban area plays a role as the capital service centre, which indicated by the facilitation of capital services, such as bank and cooperation.

Based on the interview with several heads of farmer group, it can be showed that mostly farmers used an individual capital in their farm businesses, as much seven farmer groups or $87.50 \%$. There was a farmer who used a cooperation and bank services, only one farmer group or $12.50 \%$. The cooperation and bank facilitation which are used by the farmer are in the Rimo village, placed in the urban area. This condition explains that the Rimo village in the urban area plays a role as the capital service centre, but the existence of those service facilities are mostly have a poor connection to another farmer group which are from the rural area.

Those data are strengthened by the interview results with each head of farmer groups. According to the statement from each head of farmer groups, it can be showed that most of the farmer group has not accessed the service from the bank and the cooperation yet.

The farmer group of Budidaya Lestari, Ketapang Indah village, Singkil Utara sub-district, is one of the farmer groups who cannot access the capital facilitation in the urban area. The head of Setia Kawan's farmer group, said that: "Kalau kami kan enggak pakai koperasi, kalau masalah lokasinya karena jauh itu juga termasuk, tapi enggak terlalu masalahnya itu, karena lahan kami yang kecil-kecil itu yang buat susah, makanya kami enggak pernah minjam" Referring to this interview, it can show that the size of farm which cultivated by oil-palm's farmer group has a small size. This small farm is far away from the economical scale and the location of capital service facilities in the form of bank and cooperation where concentrated in the urban area, meanwhile the location of farmer group plantations is spreading in the rural area where is relative far away, so the service facility is difficult to reach.

There is also a Setia Kawan's farmer group who located in the Suka Damai village, Singkil sub-district, is the only farmer group who accessed the capital facility. The head of Setia Kawan's farmer group, said that: "Koperasinya tiap hari jalan kemari, jadi sebenarnya kami gak nemu kendala. Yang repot orang koperasilah, kan lumayan juga ke sini, kan datang dia kesini tiap hari bayar nyicil, tiap sore lah didatanginya kami, tapi setau saya tidak semua desa didatangi koperasi keliling karena desa disini berpencar-pencar dan berjauhan" Refersing to these interview results, it knows that the farmer group can access capital because the existence of mobile cooperation who visites the farmer group routinely. This thing including explains not all the villages can be accessed by the mobile cooperation because of the intorelant mileage.

The oil-palm farm is the capital intensively business, while in general, the oil-farm farmer is weak in the capitalization. The minimal of capital flow showed that the low ability of oil-palm farmer to develop its business. All of the farmer groups also did not get capital's help from the private company. It is one of the obstacles to develop the farm business in the Aceh Singkil district. According to Hossain and friends (2019), several factors 
that have key roles to increase the relationship between the rural and urban area are the improved transportation and communication networks, the better access in the market, and the availability of funds through the government and the private companies.

\section{The Shopping Flow}

The shopping flow of farm business is divided into farming tool which using for farm activities, such as seed, manure, pesticide, and permanent tool. The regional interaction can be seen from the famer's mobility to get farming tool needs, and it can also be seen from the farmer's origin and the local facility of farming tool buying-selling services. The detailed interview results about the shopping flow of farm business can be shown in the Table 3.

Table 3. The farmer's origin and The Location of accessed farming tool's stall

\begin{tabular}{|c|c|c|c|c|}
\hline No & Location of Farmer Group & Status & $\begin{array}{l}\text { Location of accessed } \\
\text { farming tool's stall }\end{array}$ & Status \\
\hline 1 & Suka Damai Village & Rural Area & Rimo Village & Urban Area \\
\hline 2 & Ketapang Indah Village & Rural Area & Rimo Village & Urban Area \\
\hline 3 & Tanah Merah Village & Rural Area & Rimo Village & Urban Area \\
\hline 4 & $\begin{array}{l}\text { Pangkalan } \quad \text { Sulampi } \\
\text { Village }\end{array}$ & Rural Area & Pangakalan Sulampi Village & Urban Area \\
\hline 5 & Sukerejo Village & Rural Area & Lipat Kajang Atas Village & Urban Area \\
\hline 6 & Lae Pinang Village & Rural Area & Rimo Village & Urban Area \\
\hline 7 & Sumber Mukti Village & Rural Area & Rimo Village & Urban Area \\
\hline 8 & Biskang & Rural Area & Rimo Village & Urban Area \\
\hline
\end{tabular}

Source: Interview Results, 2019

Based on the interview results in the table 3, it knows that the needed farming tool of all farmer groups can be fulfilled by the existed farming tool's stall, with the details as follows: seven farmer groups or $87.50 \%$ get a farming tool from Rimo and Lipat Kajang Atas villages placed in the urban area, meanwhile one farmer group or $12.50 \%$ gets a farming tool from Pangkalan Sulampi village placed in the rural area. It shows that the shopping flow binds up well between the rural and urban area.

This thing is confirmed by the interview results with each head of farmer groups. According to the statement from each head of farmer groups, it knows that all farmer groups have accessed the facilitative service of farming tool.

One of the farmer groups who is shopping the needed farming tool in the urban area routinely, is Lee Hama Indah farmer group, Lae Pinang Village, Singkohor Sub-district. The head of farmer group, Lee Hama Indah said refersing to the interview that the consideration when choosing the addressed facility of farming tool was the completing of farming tool facilities, and the cheaper price of farming tool, and the near distance and ability to reach.

There is also Maju Jaya farmer group, Pangkalan Sulampi Village, Suro Sub-district is the only farmer group who accessing farming tool needs in the rural area. The head of Maju Jaya farmer group said that: "kami beli pupuknya di Pangkalan Sulampi sini, sama agen, kami belik yang bersubsidi, kalo gak mana tahan, belik pupuk gak banyak, kalo dari inikan bisa kredit, kadang kita ambil dulu kan, bayarnya nanti, itu pun kalok ada bayarnya, kadang gak dibayarpun. Kendala ke Pangkalan Sulampi tidak ada, memang aku yang jemput pupuknya, jalan pun bagus, dekat jugak. Gak ada masalah lah". Refersing to the interview results, it shows that the selection of location for the fulfillment of needed farming tool in the rural area are because the minimum of 
needed farming tool, the negotiable financing, and the near distance with the farm location.

Based on the several explanation, it shows that actually, the existence of service farming tool facilities is evenly quite distribution, however most of the farmer group tends to choose using the service facilities in the urban area, because the bargaining position in the urban area towards the fulfillment of farming tool is quitely high. According to Aulia (2020), the people's movement pattern from the rural area into the urban area is dominated by the community who has a purpose to shop. The factors that motivate human's movement from the rural into urban area are the availability of shopping facilities, the quality of tool services, and the convenience to reach facilities.

\section{The Raw Material Flow}

The oil-palm bunches is a product from the oil-palm farm. The oil-palm farm can be used as the raw material for industrial process. The resulting product is a intermediate goods in the form of Crude Palm Oil (CPO). Condescend with that process, it can be said that the oil-palm bunches which is resulted by the public's farm, has a linkage with the processing oilfarm's company. The details of interview results about the oil-palm bunches plot which will be marketed to oil-palm factory can be seen in the Table 4 .

Table 4. The Origin of Farmer Group and The Purpose of Oil-palm Bunches Distribution

\begin{tabular}{|c|c|c|c|c|c|}
\hline No & $\begin{array}{l}\text { Location of Farmer } \\
\text { Group }\end{array}$ & Status & $\begin{array}{l}\text { The Kind of } \\
\text { Distributor }\end{array}$ & $\begin{array}{c}\text { Location of Puposed } \\
\text { Factory }\end{array}$ & Status \\
\hline 1 & Suka Damai Village & Rural area & Agent & $\begin{array}{l}\text { PT Astra Agro Lestari, } \\
\text { Pandan Sari Village }\end{array}$ & Rural area \\
\hline 2 & Ketapang Indah Village & Rural area & Agent & $\begin{array}{l}\text { PT Astra Agro Lestari, } \\
\text { Pandan Sari Village }\end{array}$ & Rural area \\
\hline 3 & Tanah Merah Village & Rural area & Agent & $\begin{array}{c}\text { PT Naffasindo, } \\
\text { Bukit Harapan Village }\end{array}$ & Rural area \\
\hline 4 & $\begin{array}{l}\text { Pangkalan Sulampi } \\
\text { Village }\end{array}$ & Rural area & Agent & $\begin{array}{l}\text { PT Naffasindo, Bukit } \\
\text { Harapan Village }\end{array}$ & Rural area \\
\hline 5 & Sukerejo Village & Rural area & Agent & $\begin{array}{l}\text { PT Astra Agro Lestari, } \\
\text { Pandan Sari Village } \\
\text { PT Runding Putra }\end{array}$ & Rural area \\
\hline 6 & Lae Pinang Village & Rural area & Agent & $\begin{array}{c}\text { Persada, Lae Pinang } \\
\text { Village }\end{array}$ & Rural area \\
\hline 7 & Sumber Mukti Village & Rural area & Agent & $\begin{array}{c}\text { PT Runding Putra } \\
\text { Persada, Lae Pinang } \\
\text { Village }\end{array}$ & Rural area \\
\hline 8 & Biskang Village & Rural area & Agent & $\begin{array}{c}\text { PT Delima Makmur, } \\
\text { Situban makmur } \\
\text { Village }\end{array}$ & Rural area \\
\hline
\end{tabular}

Source: Interview Results, 2019

Based on the Table 5, it shows that the raw material production from the villages was placed in the rural area, all of them is distributed into the oil-farm factory which also $100 \%$ placed in the rural area. Because of that, it can be said that the raw material flow did not bind up with the urban area.

Moreover, it can be seen that the supply chain for oil-palm bunches from all the farmer groups did not send directly to the factory, but through the agent first. The collective agent in the village plays a role as an agency or supplier of oil-palm 
bunches to the factory. The agency in the production centre villages buys the oilpalm bunches from the oil-palm farmer with the variative prices. The collective agent in the village has a supplied quota in each of palm oil's companies with few obligation that have to be fulfilled. The consequence of oil-palm bunches sales chain to the long-processing factory influenced the low price of oil-palm bunches in the farmer level.

Referring to the company or factory, the purchase value of oil-palm fruit followed the market price mechanism, meanwhile a different selling price from the farmers is influenced by the variation of transportation cost. The different cost connected with the mileage from oil-palm bunches productional zone into the processing oil-palm factory. The farer mileage will decrease the price of oil-palm bunches on the farmer level as the result of the long distribution plot and the higher transportation cost. Based on this condition, it can be known that the agent in this distributive scheme got highly value add, so it decreased the farmer's income. According to Hidayat (2017), the characteristic of oil-palm farmer with owning the smallholder generally at the lowest bargaining position because of the length of oil-palm bunches' supplied chain, it makes a low price in the farmer level, even this condition becomes worse with the minimum access to use the latest technology in the oil-palm cultivation.

This is strengthened by the interview results with each head of farmer groups. Based on the statement from each head of farmer groups, it shows that the reasons of using an agency are: (1) the distance between farm's land and the oilpalm processing factories is relatively far, and (2) the oil-palm farming land which attempted by the farmer has a small size, so that the yields' production do not fulfill the requested factory yet, because of that, the agency has a fuction as a yields' collector from each farmers in order the request from the factory can be fulfilled.
In addition, the consideration of choosing factories location aims to distribute an oil-palm bunches, there are: (1) the selling price of an oil-palm which fluctuative and variative every factory, so basically the choosing of distributive location is following the highest offer every month, (2) the distance between the farmer's plantation land and the factory, with the argumentation that the choosing of factories' distributive location depends on the lowest transportation costs in order the received advantage is proper.

There were several obstacles when distributed the oil-palm bunches from the farm land to the oil-palm processing factories, such as: (1) the distance from the farm land into the oil-palm processing factories is relatively far, and (2) the land ways in the oil-palm factory area and the district ways in the several villages have an inadequate condition. According to Muta'ali (2014), the lagged accessibility region towards the center of socioeconomic activities, especially the central production and the marketing generally were not supported by the facility and infrastructure of goods transportation and the passenger that relate with the needs and characteristics of its region.

\section{The Intermediate Goods Flow}

The intermediate goods or Crude Palm Oil which produced from the palm oil processing factories can be reprocessed with the aims to produce the finishing goods, such as cooking oil, cosmetics, soaps, and etc. The Intermediate goods flow is related with the industrial performance of palm oil from upstream to downstream. The hilirisation of oil-palm is wished can give a benefit in increasing the farmer's income and businessman/woman, creating a valueadded in domestic, absorbing a worker, and exporting in processed form as a foreign exchange earner.

Connecting with the intermediate goods or product downstream of oil-palm land, The head of administration in PT Naffasindo said that: "Kalo di Singkil ini 
cuma sampe barang setengah jadilah, kan gak kami olah ini jadi barang jadi, kayak sabunsabun, minyak makan, gak kami olah disini, belum ada pabrik untuk barang jadi disini. CPO kami kirim lagi ke Medan, rata-rata 425 ton CPO perbulan kami kirim ke Medan. Kalau misalnya buka pabrik, bisa diolah jadi barang jadi tentunya lebih banyak penghasilan pasti, pekerja juga banyak butuhkan, ya itulah intinya semua CPO ini ujungnya diekspor ke Malaysia, inikan yang punya orang Malaysia. Jadi tujuan ekspor semuanya ke Malaysia ini, tapi ini tanah HGU, bukan punya orang Malaysia. Pengennya sih bisa ekspor dari sini, Singkil ini pun jadi kaya nantik kalo ekspor dari sinikan. Banyak penghasilannya, dan butuh tenaga kerja udah pasti itu, tapi sampe sekarang belum pernah ekspor sendiri. Saran saya, menyimpulkan inilah, ada jalan yang bagus, pelabuhan laut pun ada, dan jalin kemiraan kami sama PT lainnya untuk bisa ekspor langsung, selama ini orang Medan sana lah yang diuntungkan karena punya pelabuhan Belawan" According to the interview with factory's head of administration, it can be known that wholly or $100 \%$ of Crude Palm Oil's production will resend to abroad through Belawan harbor in Medan. It indicates that the connection between rural and urban area in Aceh Singkil District is not binding up. Based on the statement from factories head of administration, it showed that the cause Aceh Singkil district only plays a role as a Crude Palm Oil's production, is the minimum of export activities' supported infrastructure, especially sea harbor and Crude Palm Oil terminal, also the minimum of the partnership with another oil-palm's company in the scope of Aceh Singkil district.

Based on the previous section, it can be known that Aceh Singkil district was only playing a role as a Crude Palm Oil's production area. The over Crude Palm Oil's production results were unable to bring the Original Local Government
Revenue because all the Crude Palm Oil's production are sold through Medan, moreover the Aceh Singkil district did not get advantage from the export's tax. Finally, the big yield of natural resources in this region are absorbed by the territory beyond it, and the public only enjoys less advantage. The absence of added-value from the production results also cause the lack opportunity of local community to increase the living standards. According to Muta'ali (2014), the newly developmental territory only tends to produce primary product, the capital is out of its territory into the more develop territory, also known as backwash effect. In addition, its territory product is into abroad's market without give an added-value to the lagged territory, and in another side, the capital from abroad tends to come into the more develop territory.

\section{The Income Flow}

The farmer gets an advantage from the sales of its farm product, an oil-palm bunches. The farmer's income is very influenced by the quantity and the selling price of oil-palm bunches which set when transaction. The determination of oil-palm bunches price is done by the Provincial Government, the City/District Government, the Plantation Office, and the Company. The selling price of oil-palm bunches is minimal set in once in a month which is suitable with the realization of export and local sales from each companies (The Regulation of Agriculture Minister, Number 395, Year 2005). The detailed income of each farmer group members can be seen in the Table 5

Table 5. The Total of Income Averages from the Plantation Products Farmer Group in the Aceh Singkil District in 2019 


\begin{tabular}{|c|c|c|c|c|c|}
\hline No & Source of Income Flow & Status & $\begin{array}{l}\text { Location of Farmer } \\
\text { Group }\end{array}$ & Status & $\begin{array}{l}\text { The Income Averages of } \\
\text { family's head in a month } \\
\text { (IDR) }\end{array}$ \\
\hline 1 & $\begin{array}{l}\text { PT Astra Agro Lestari, } \\
\text { Pandan Sari Village }\end{array}$ & Rural area & $\begin{array}{l}\text { Suka Damai } \\
\text { Village }\end{array}$ & Rural area & $1,400,000$ \\
\hline 2 & $\begin{array}{l}\text { PT Astra Agro Lestari, } \\
\text { Pandan Sari Village }\end{array}$ & Rural area & $\begin{array}{l}\text { Ketapang Indah } \\
\text { Village }\end{array}$ & Rural area & 700,000 \\
\hline 3 & $\begin{array}{c}\text { PT Naffasindo, } \\
\text { Bukit Harapan Village }\end{array}$ & Rural area & $\begin{array}{l}\text { Tanah Merah } \\
\text { Village }\end{array}$ & Rural area & $1,600,000$ \\
\hline 4 & $\begin{array}{l}\text { PT Naffasindo, Bukit } \\
\text { Harapan Village }\end{array}$ & Rural area & $\begin{array}{c}\text { Pangkalan Sulampi } \\
\text { Village }\end{array}$ & Rural area & 900,000 \\
\hline 5 & $\begin{array}{l}\text { PT Astra Agro Lestari, } \\
\text { Pandan Sari Village } \\
\text { PT Run8ding Putra }\end{array}$ & Rural area & Sukerejo Village & Rural area & 900,000 \\
\hline 6 & $\begin{array}{c}\text { Persada, Lae Pinang } \\
\text { Village }\end{array}$ & Rural area & Lae Pinang Village & Rural area & $1,200,000$ \\
\hline 7 & $\begin{array}{l}\text { PT Runding Putra Persada, } \\
\text { Lae Pinang Village }\end{array}$ & Rural area & $\begin{array}{l}\text { Sumber Mukti } \\
\text { Village }\end{array}$ & Rural area & $1,100,000$ \\
\hline 8 & $\begin{array}{l}\text { PT Delima Makmur, } \\
\text { Situban makmur Village }\end{array}$ & Rural area & Biskang Village & Rural area & $1,200,000$ \\
\hline \multicolumn{5}{|c|}{ The Income Averages of Each Farmer Group Members in a Month } & $1,125,000$ \\
\hline
\end{tabular}

Source: Interview Results, 2019

From the interview results with the several head of farmer groups in the table 7 , it can be known that the income flow which received by farmer group in the rural area, wholly or $100 \%$ was coming from the factory where also placed in the rural area too. It indicates that the income flow between the rural-urban linkage is not binding up. There is also the income averages that is received by the farmer every month, totally IDR $1,125,000$. The farmer's total income is lower than the applicable-Provinicial Minimum Wage in Aceh Province in 2019 with a nominal amount IDR 2,916,810 (The Regulation of Aceh Government, Number 98, Year 2019). Connected with the income below the Provinicial Minimum Wage, the farmer have to do various attempts aims to discover the lack income from that farm.

It can be strengthened by the data of interview results with each head of farmer groups. Based on the interview results with each head of farmer groups, it showed the connection with low income certainty from the oil-palm farm, and it made the oil-palm farmer in Aceh Singkil district did not only depend themselves on the oil-palm farm business. There are various kind of the others businesses which owned by the farmer, such as: (1) planting another plantation crops, such as: durian and corn, (2) planting vegetables, such as: long bean and peanuts, (3) catching a fish and lokan (shell) in the river, (4) becoming an entrepreneur with opening a stall, and (5) becoming a travel driver. Based on the previous thing, in general, the concept of various livelihood sources have been implemented in the public for a long time ago, however it has not been maximally attempted. According to Agustira, and friends (2015), the problems of low productivity from the oilpalm farmer because of the low farmer foundation, and the limited capital. Therefore, a small-holder farmer is often to cultivate the oil-palm using the intercropping method with another commodities, or do another jobs.

\section{CONCLUSION}

Based on the several condition of rural-urban linkage which have been explained before, it can be known that the farm activities in the rural area and the interaction towards service facilities which placed in the urban area have not been directly bound up. The economical linkage 
which has a good binding between the rural and urban area is the shopping flow, meanwhile the capital flow is less binding up with villages which placed in the urban area. In addition, the raw material flow, the intermediate flow, and the income flow which are absolutely not binding up. Moreover, the intermediate goods flow binds up in the outside of territory, so the acquisition of added-value goes to others areas. Based on that condition, it can be concluded that the rural and urban area develop individually, as if separated or it can be said the rural-urban linkage is relatively limited. It is potentially appeared the development gap and the high poverty rates, especially in the rural area.

The suggestions that can be given as the contribution of this research are it will be better to do the optimized efforts of service facilities in the urban area, especially the facilities that supported the development of plantation sector and industry, such as a the production facility stalls, the cooperation, the bank, the factory, and the harbor, and the development of rural's territory as a central farm production can be pursed through the partnership between the farmer group, the cooperation, and the bank, also the private farm's company.

\section{ACKNOWLEDGEMENT}

The gratitude is delivered by the writer to Dr. Agus Purwoko, S.Hut, M.Si and Dr. Rujiman, M.A who have guided and gave a suggestion through the finishing of this research, also all those who have helped until this research can be finished.

\section{REFERENCES}

Agustira, M. A., Amalia, R., \& Nurkhoiry, R. (2015). Program sawit untuk rakyat (Prowitra) sebagai upaya peningkatan produktivitas, pemberdayaan, keberlanjutan, dan kesejahteraan pekebun kelapa sawit rakyat. In Prosiding Seminar Nasional "Perlindungan dan Pemberdayaan Pertanian dalam
Rangka Pencapaian Kemandirian Pangan Nasional dan Peningkatan Kesejahteraan Petani (pp. 315-24).

Akkoyunlu, S. (2015). The potential of rural-urban linkages for sustainable development and trade. International Journal of Sustainable Development \& World Policy, 4(2), 20-40.

Arikunto, S. (2010). Prosedur Penelitian Suatu Pendekatan Praktik, Jakarta: Rineka Cipta, Cet. Ke-13.

Aulia, B. U. Overview: Faktor Pendorong Terjadinya Keterkaitan Kota-desa dari Segi Pergerakan Orang antara Kota Mojokerto dengan Wilayah Peri-urban di Kabupaten Mojokerto. Desa-Kota, 2(1), 58-69.

Badan Pusat Statistika, Kabupaten Aceh Singkil dalam Angka 2019, Singkil: BPS

Dinas Kehutanan dan Perkebunan (2019). Luas Areal dan Produksi Komoditas Perkebunan Rakyat Kabupaten Aceh Singkil Angka Tetap Tahun 2018, Singkil, Dishutbun

Douglass, M. (1998). A regional network strategy for reciprocal rural-urban linkages: an agenda for policy research with reference to Indonesia. Third world planning review, 20, 1-34.

Hidayat, N. K. (2017). At the bottom of the value chain: Sustainability certification and the livelihoods of palm oil smallholders in Indonesia.

Hossain, N., Das, A., Labib, S. M., \& Mohiuddin, H. (2019). Recognition of Rural-Urban Linkage Throughunderstanding the Potential Impact of Growth Center: A Case Study of Paragram Hut, Nawabganj, Dhaka. Nawabganj, Dhaka (January 4, 2019).

Mulyana, W. (2014). Rural-urban linkages: Indonesia case study. Urban and Regional Development Institute (URDI) J, Indonesia, editor. Santiago, Chile: RIMISP.

Muta'ali, L. (2014). Perencanaan Pengembangan Wilayah Berbasis 
Pengurangan Risiko Bencana. Yogyakarta: badan Penerbit Fakultas Geografi (BPFG). Bahasa Indonesia.

Peraturan Gubernur Aceh Nomor 98 Tahun 2019 Tentang Upah Minimum Regional di Provinsi Aceh

Peraturan Kepala Badan Pusat Statistik No 37 Tahun 2010 Tentang Klasifikasi Perdesaan dan Perkotaan

Peraturan Menteri Pertanian No 324 Tahun 2005 tentang Penetapan Harga TBS
Rondinelli, D. A. (1985). Applied Methods of Regional Analysis: The Spatial Dimension of Development Policy. Boulder, Colorado. Westview Press, Inc. Rondinelli, DA (1984)." Cities and agricultural development: The urbanrural connexion", in Regional Development Dialogue,(Spring) volume, 5, 1-18.

Sugiyono, P. (2011). Metodologi penelitian kuantitatif kualitatif dan R\&D. Alpabeta, Bandung. 